〔ミニレビュー〕

ウシゲノム解析用ツールの開発とゲノム解読の現状

高須賀晶子

（社）畜産技術協会附属動物遺伝研究所

\title{
Development of bovine genomic tools and the progress of the bovine genome sequencing project
}

\author{
Akiko TAKASUGA
}

Shirakawa Institute of Animal Genetics

\section{1. はじめに}

ゲノム解析のツールとして、連鎖地図、RH 地図、 $\mathrm{BAC}$ 整列地図など（後に詳述する）があげられるが、 究極は全ゲノム塩基配列の決定である。2001 年にヒト ゲノムドラフト配列が決定されて以降、哺乳動物とし ては、マウス (2002 年)、ラット (2004 年)、チンパン ジー $(2005$ 年)、イヌ (2005 年) のゲノム配列が決定さ れ、次いで、今、ウシのゲノム配列が決定されつつあ る。家畜の中では、ニワトリに次ぐ 2 番手となり、 3 番手にはブ夕の配列決定が予定されている。ウシのゲ ノム塩基配列決定は、米国テキサス大学ベイラー校の ヒトゲノムシークエンシングセンターで行われている が、ここは、一ヶ月で一つの哺乳動物種ゲノムの塩基 配列を読む力を持っているそうだ。が、実際は、最初 にあげたような地図 (それも、多数のマーカーを持つ 高密度のもの) がなければ、染色体上の位置のわから ない、短い配列断片が大量にできるだけで、ゲノム配 列にはならない。

動物遺伝研究所では、ウシゲノムプロジェクトが始 まる以前から、研究を効率良く進めるにはゲノム解析 用ツールの充実が必須と考え、米国農務省肉畜研究セ ンター (USDA-MARC) と共同で高密度連鎖地四の作成 に、また、ネバダ大との共同で高密度 RH 地図の作成 に着手した。その後、米国を中心とした国際コンソシ アム (日本の研究機関は参加していない) が結成され、 BAC フィンガープリント整列地図などが作成されつつ ある。ウシゲノム塩基配列については、2004 年 9 月に、 3 x WGS (Whole Genome Shotgun) 配列 (全ゲノムを断 片化した配列を、のべで全ゲノムの 3 倍に相当する長 さになるまで読んだもの)が、ついで、2005 年 3 月に、 $6 \mathrm{x}$ WGS 配列が公開された。ここでは、私たちの作成
した高密度連鎖地図および RH 地図を、ウシゲノム解 読の現状とともに紹介したい。また、ゲノム解析に詳 しくない方のために、次項で各地図の特長と役割につ いて記したので、参照していただければと思う。

\section{2. 各々の地図の特徴と役割}

地図には、連鎖地図と物理地図 $(\mathrm{RH}$ 地図や BAC 整 列地図)とがあり、連鎖地図は、マーカー間の距離を 遺伝的な物差し (連鎖の度合い、すなわち遺伝上の組 み換え頻度) で測り、並べたものであるのに対して、 物理地図はDNAの長さという物理的な物差しの上に マーカーを並べたものである。

\section{（1）連鎖地図}

減数分裂の過程において、相同染色体間の組み換え が起こることが知られているが、その際、ある 2 マー カーの位置 (座位という) が同一染色体上で近くにあれ ばあるほど、その間で組み換えの起こる確率は低くな り、ともに親から子に受け継がれる (連鎖する) 確率が 高くなる。一方、距離が遠ければ、その間で組み換え の起こる確率は高く、連鎖しない。多数の減数分裂が 観察できる大きな家系で、各マーカーの伝わり方を調 ベると、マーカー間の組み換え頻度が算定でき、遺伝 的尺度上にマーカーを並べることができる。

連鎖地図のマーカーには、相同染色体間を識別でき

連絡先：高須賀晶子、（社）畜産技術協会 附属動物遺伝研究所 T 961-8061 福島県西白河郡西郷村大字小田倉字小田倉原一

(e-mail: takasuga@siag.or.jp) 
る多型性が必要である。ゲノム上には、マイクロサテ ライトと呼ばれる短い塩基配列の繰り返しから成る反 復配列 $\left((\mathrm{CA})_{\mathrm{n}}\right.$ など $)$ が散在しており、その繰り返し数 $\mathrm{n}$ は各相同染色体に固有であるので、連鎖地図のマー カーとして汎用される。

連鎖地図の役割には、大きく2つがあり、ひとつは、 遺伝病や経済形質などの座位をマッピングするための マーカーの提供、もう一つは、物理地図作成のための 足場の提供である。

\section{(2) $\mathrm{RH}$ 地図}

RH 地図は、放射線照射体細胞雑種 (Radiation Hybrid) 地図のことで、一定量の放射線照射で切断されるゲノ ム DNAの長さが尺度となっている。正常細胞（私たち の場合は、ウシ正常細胞)の染色体を放射線照射によ り断片化した後、ハムスターなどの絜歯類由来の細胞 (宿主細胞) と融合させ、100 種類程度の融合細胞から 各々 DNAを回収してセットとした「RHパネル」を用 いて、地図を作成する。 RH パネルを構成する各 DNA には、断片化された正常細胞 (ウシ) 由来の染色体の一 部が宿主細胞の染色体内に組み达まれて保持されてい るので、任意のマーカーをPCR 増幅することで、ど の融合細胞 DNA がそのマーカーを含む染色体領域を 保持していたか否かを知ることができる。ある2つの マーカーが近接していれば、各 RHパネルにおける PCR 増幅の有無のパターンは相似し、離れていれば相 似しない。このような原理で、各マーカーの順番とマ 一カー間距離が算定できる。

$\mathrm{RH}$ 地図のマーカーは、連鎖地図のマーカーのよう に多型性を必要としないため、遺伝子配列からマーカ ーを設計してマッピングすることにより、遺伝子地図 を作ることができる。一方で、RHマッピングは PCR 増幅の有無のみに依拠するため、エラーを除くことが 難しい。そこで、RH 地図の信頼性を確保するために は、連鎖地図の情報を基本にしなければならない。つ まり、連鎖地図上で染色体上の位置が特定されている マーカー、通常はマイクロサテライトマーカー、の並 ぶ順番の情報を用いて、RH 地図のフレームワークを 構築する(枠作りを行う)。照射放射線量が高いほど、 染色体は細かく分断されて RH 地図の解像度は上がる ものの、これらを正確につなぐためには、数多くのマ 一カーが必要になる。したがって、解像度の良い RH 地困を作るためには、高密度連鎖地図の作成が不可欠 である。

$\mathrm{RH}$ 地図の有用性は、第一に、遺伝子地図を作るこ
とができるということで、これによって、他の種、例 えばヒトとのゲノム比較地図を作成することができ、 比較地図を通じて、ヒトなどの豊富な遺伝子情報をは じめとするゲノム情報を利用できるようになることで ある。連鎖地図との統合によって、遺伝病などをマッ ピングした染色体領域が、ヒトのどの染色体領域に相 当するのか、そこにはどのような候補遺伝子があるか、 を一時に知ることができる。第二に、BAC 整列地図 の作成やゲノム配列を染色体上に並べる際の足場とし て、重要である。

\section{(3) BAC 整列地図}

染色体 DNAを 150-200 kb 程度の大きさに切断し て、大腸菌細胞内で複製できるように人工染色体に組 み込んだものを BACクローンといい、これを染色体 上の順番で並べたものが BAC 整列地図である。 $\mathrm{BAC}$ クローン DNA を特定の制限酵素で切断したパターン (フィンガープリント) 同士を比較し、パターンの相同 性に基づいてつなぎ合わせることによって、染色体上 の順番にBACクローンを並べることができる。この ようにして並べた BACクローンの一群をコンティグ と呼ぶ。コンティグに含まれるマーカーを用いて、 RH 地図と統合することにより、コンティグを染色体 上に並べた BAC 整列地図ができる。

$\mathrm{BAC}$ 整列地図があるか否かは、ゲノム配列決定の 質を左右する。ゲノム配列決定には、通常、全ゲノム を断片化した配列を全ゲノムの 6 倍長読んだものと、 整列化したBACクローンを全ゲノムの 2 倍長読んだ ものとを合わせて用いる。後者を加えることにより、 配列間のギャップやつなぎ間違いの少ないゲノム配列 が得られる。

\section{3. 高密度連鎖地図の作成}

ウシでは、1997 年に米国農務省肉畜研究センター (USDA-MARC) らのグループが、1,250 個の DNA マー カーを含む連鎖地図を作成したが（Kappes ら 1997）、 その後は、形質のマッピングにはこの程度の密度でも 差し支えないことと、マーカーの開発には多大な労力 と費用がかかることから、連鎖地眓の更新はなされて いなかった。しかし、疾病や経済形質をマッピングし た後の原因遺伝子の同定を視野に入れた時、マッピン グした領域ごとにマーカーを高密度に開発するので は、大変に効率が悪い。そこで、全ゲノムを対象にラ ンダムにマーカーを開発し、3,000 個のマイクロサテ ライトマーカーを含む連鎖地図を作ることを目標とし 

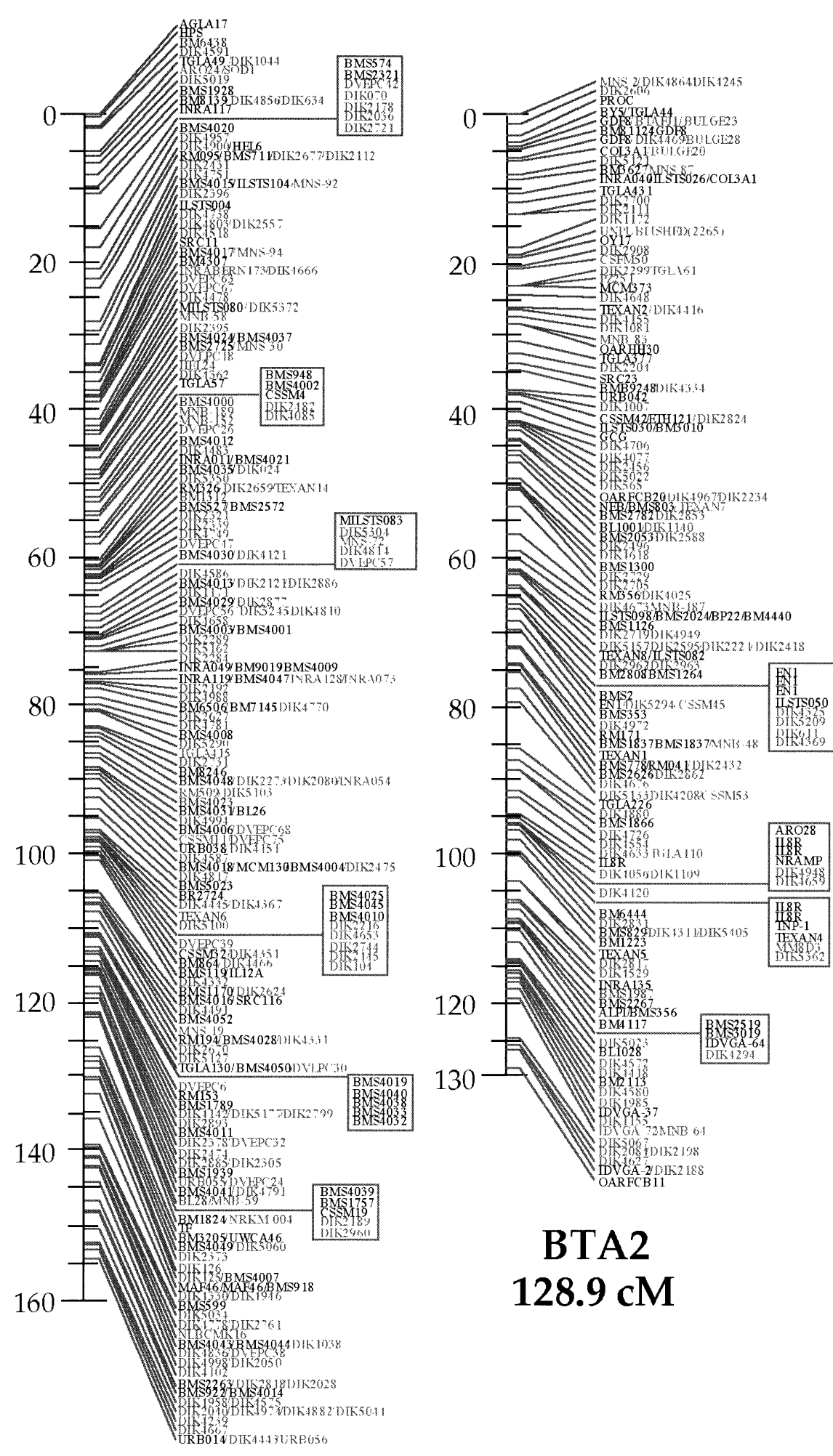

\section{BTA2 \\ $128.9 \mathrm{cM}$}

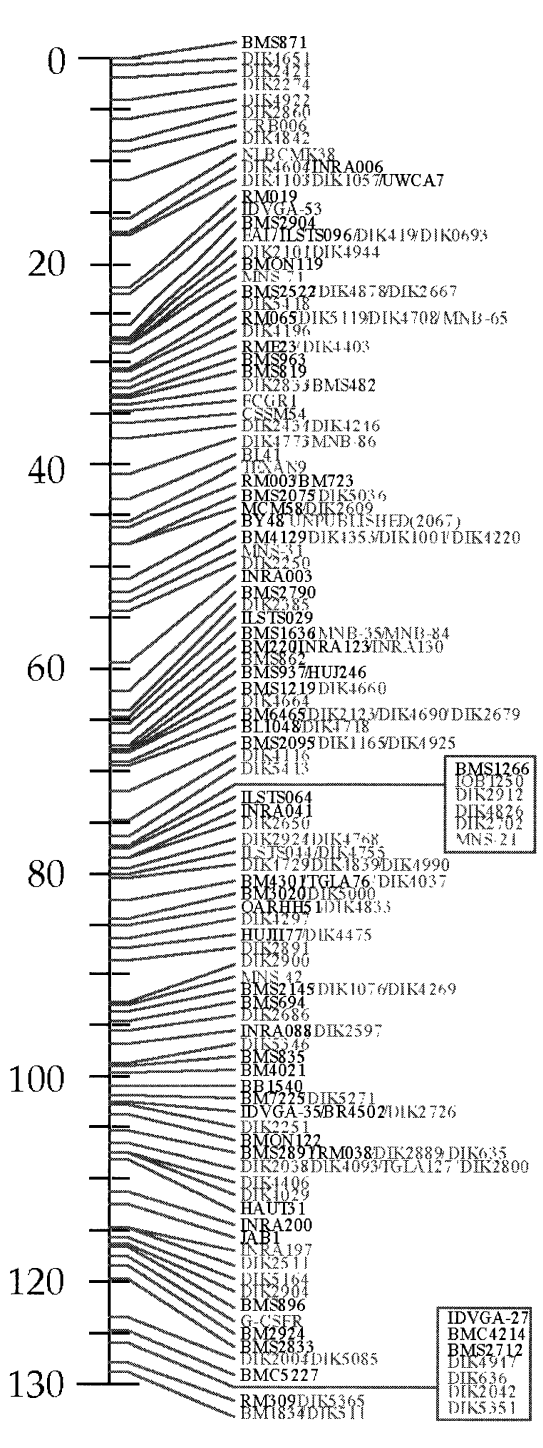

\section{BTA3}

\section{$128.9 \mathrm{cM}$}

\section{BTA1 \\ $154.7 \mathrm{cM}$}

図 1. Shirakawa-USDA 連鎖地図

第 1 番染色体から第 3 番染色体(BTA 1-3)までを示した。その他の染色体およびマーカー情報は、 http://www.marc.usda.gov/genome/cattle/cattle.html で閲覧できる。 
$\left(c R_{7,000}\right)$ SUNbRH linkage

(cM)
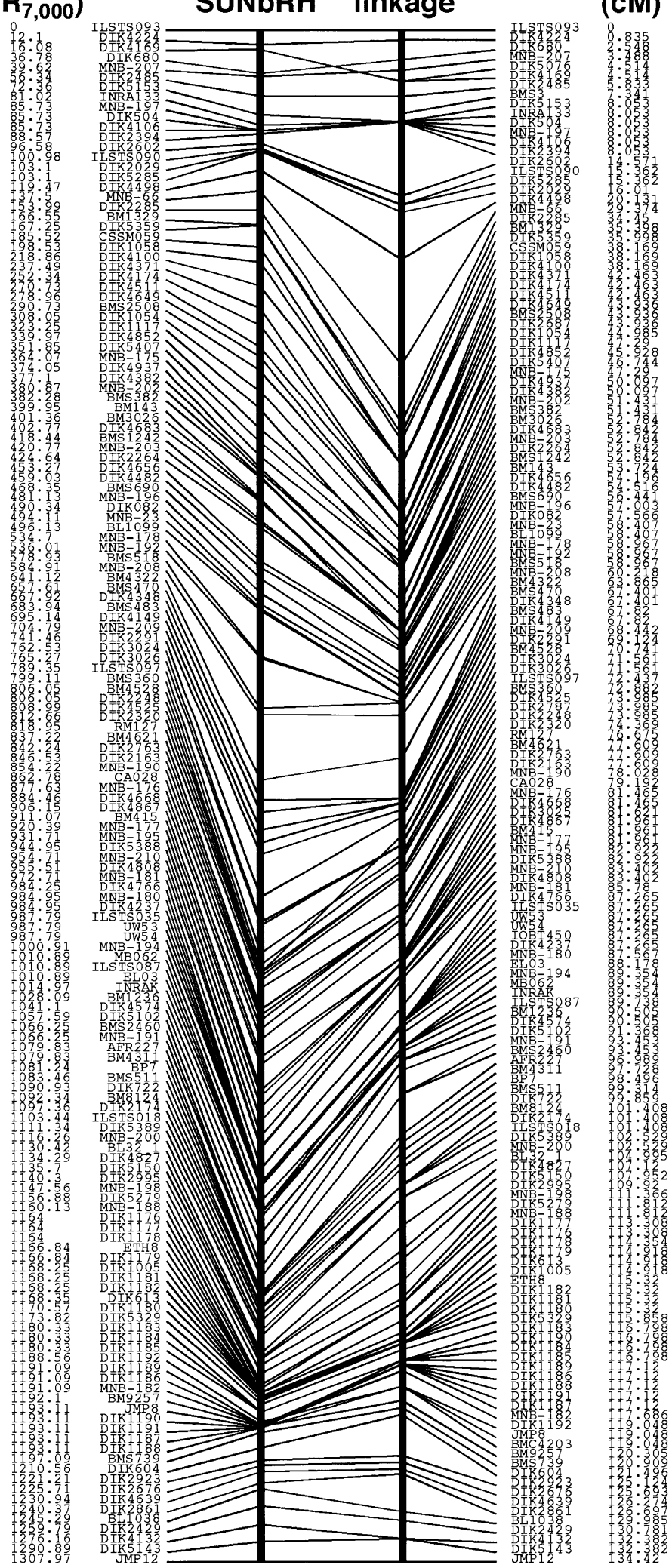

図 2.SUNbRH フレームワーク地図と連鎖地図との対応

例として第 6 番染色体を示した。その他の染色体については、 http://www.animalgenome.org/cattle/maps/RHMap3/で閲覧できる。 
て作成に取りかかった。そして、2,293 個のマイクロ サテライトをUSDA-MARCの連鎖地図に追加するこ とによって、3,802 個のマイクロサテライトマーカー を含む 3,960 個のマーカーから成る地眓を作成し、 Shirakawa-USDA 連鎖地図として発表した（Iharaら 2004)。

連鎖地図の解像度は、マッピングに用いる標準家系 の規模に依存するので、USDA-MARC のウシ標準家系 では、解像度の限界は $0.8 \mathrm{cM}(=$ 約 $800 \mathrm{~kb})$ である。 Shirakawa-USDA 連鎖地図の 3,960 個のマーカーは、 2,423 ポジションの「点」であり、マーカー間隔は平均 $1.4 \mathrm{cM}$ であった。連鎖地図の更新により、マーカー間 隔が $10 \mathrm{cM}$ を超えるギャップは、X染色体の一箇所の みとなり、全ゲノムの $51 \%$ はマーカー間隔 $2 \mathrm{cM}$ 以下 で、また、91\%は $5 \mathrm{cM}$ 以下でカバーされた。この結 果、疾病や経済形質のファインマッピングに十分なマ 一カー密度となり、また、RH 地図の足場としても十 分なものが作成できた。

\section{4. 高密度 $\mathrm{RH}$ 地図とウシ-ヒトゲノム比較地図の作成}

2000 年に米国テキサス A\&M 大学の Womack らのグ ループが最初のウシ全ゲノム RH 地図 (5,000-rad 放射 線照射 RH パネルによる）を報告した（Band ら 2000）。 これは、319個のマイクロサテライトと 768 個の遺伝 子から成り、ウシーヒトゲノム比較地図において 105 以上のシンテニーが観察されることがわかった。2002 年には、英国のロスリン研究所やフランスの国立農業 研究機構 (INRA) などの共同で 3,000-rad 放射線照射 $\mathrm{RH}$ パネルを用いた地四が報告された（Williamsら 2002）。これは、当時の連鎖地図にマップされていた マーカーから、できるだけ多くのマーカーを用いてフ レームワークを構築しようとしたもので、1,148 個の マイクロサテライトと 90 個の遺伝子から成っていた。 前者の Womack らの RH パネルについては、イリノイ 大の Lewin らのグループが 1,913 個のマーカー(うち、 667 個をフレームワークマーカーとして使用) から成 る第 2 世代の全ゲノム RH 地図を作成し、2004 年に報 告した (Everts-van der Wind ら 2004)。しかしながら、 これらのウシ RH 地図では、フレームワークに用いた マーカー数が充分とはいえず、信頼性および解像度に 限界があると思われた。

私たちは、米国ミネソタ大 (現、ネバダ大)の Beattie 教授と共同で、7,000-rad 放射線照射 RHパネル を作成した。この RHパネル（SUNbRH パネル）を用い て、Shirakawa-USDA 連鎖地図上にマップされたマイ
クロサテライトマーカー 3,216 個を用いてフレームワ 一クを作成した。図 2 をると、連鎖地図と比較して、 マーカー同士がよく分離しており、RH 地図の解像度 のよいことが一目でわかる。

このフレームワーク上に、2,377 個の遺伝子または ESTをマップした。EST とは、ゲノム上で発現してい る配列 (遺伝子) の一部分について塩基配列を決定した もののことをいう。ここで用いたほとんどのESTは、 私たちが過去に開発したものである（Takasugaら 2001; Itoh ら 2003)。

このようにして、計 5,593 マーカーから成る RH 地 図 (SNUbRH 地図) が完成した (Itoh ら 2005)。このう ち 1,716 マーカーについて、ヒトゲノム上に相同配列 を見いだすことができ、これらを用いてウシーヒトゲ ノム比較地図を作成した (図 3)。少なくとも 161 個の シンテニーが観察され、特に 4 番、8 番、10 番、13 番、 19 番などの染色体について、過去の報告と比べて、よ り複雑なシンテニーが観察された。私たちの比較地図 で観察された全シンテニーは、ウシ RH 地困の 79\%、 ヒトゲノムの72\%をカバーしていた。また、RH 地図 $1 \mathrm{cR}$ は、約 $114 \mathrm{~kb}$ に相当すると算定された。

\section{BAC フィンガープリント地図との統合}

私たちの作成した RH 地図が物理的な実体のある染 色体地図を作成する上でどの程度有効かを、4 番染色 体を例に検証した（Itoh ら 2005）。前述のように、国際 コンソシアムでは、BACフィンガープリント地図を 作成中で、随時、データをウェブサイトで公開してい る (http://www.bcgsc.ca/lab/mapping/bovine)。そこで、4 番染色体のマイクロサテライトマーカーおよびESTに ついて BACクローンのスクリーニングを行い、ウェ ブサイトでこれらのクローンの属する BACコンティ グを検索し、BACクローンの末端塩基配列とヒトゲ ノム塩基配列との相同性の情報も含めて、ウシ染色体 上に並べてみた (図 4)。その結果、私たちの RH 地図 は、BACコンティグをウシ染色体上に並べていくの に十分なマーカー数を持つことが確認された。また、 私たちの比較地図は、BACクローンの末端塩基配列 を相同性に基づいてヒトゲノム上に並べた結果と、よ く一致しており、私たちの比較地図は十分な解像度を もつ、信頼性の高い地図であることが確認された。

\section{6. ウシゲノム解読の現状}

ウシゲノムプロジェクトは、Phase I と Phase II から 成り、Phase Iは、ウシゲノムの塩基配列決定から 
BTA 1

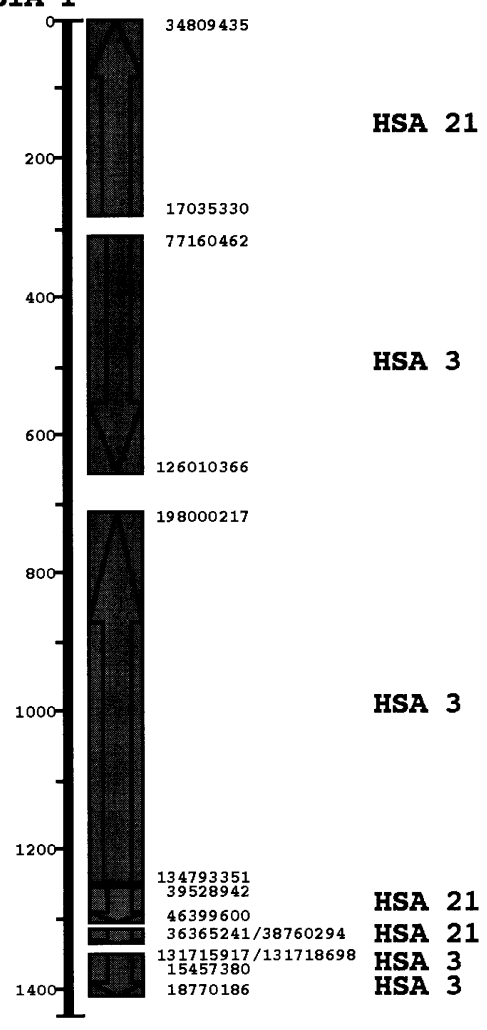

BTA 2

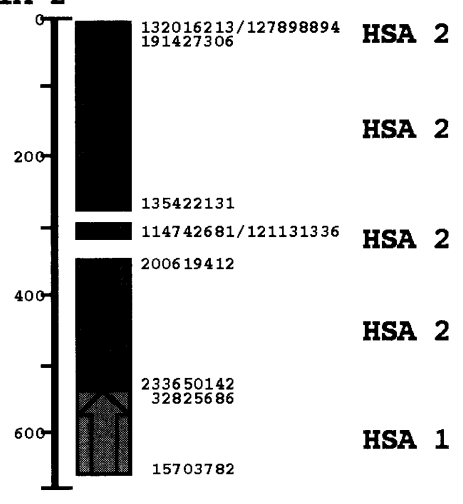

BTA 3

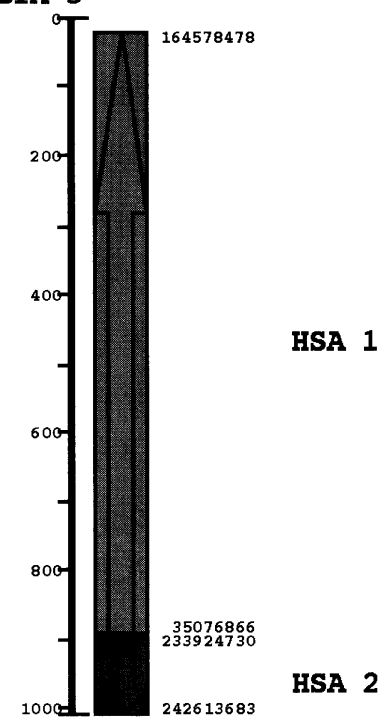

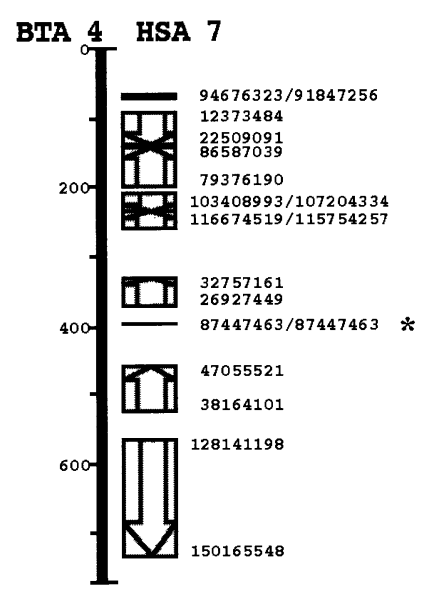

\begin{tabular}{|c|c|c|}
\hline HSA & HSA 9 & HSA 17 \\
\hline HSA & HSA 10 & HSA 18 \\
\hline HSA & HSA 11 & HSA 19 \\
\hline HSA & HSA 12 & HSA 20 \\
\hline HSA & HSA 13 & HSA 21 \\
\hline HSA & HSA 14 & HSA 22 \\
\hline HSA & HSA 15 & HSA $X$ \\
\hline & HSA 16 & \\
\hline
\end{tabular}

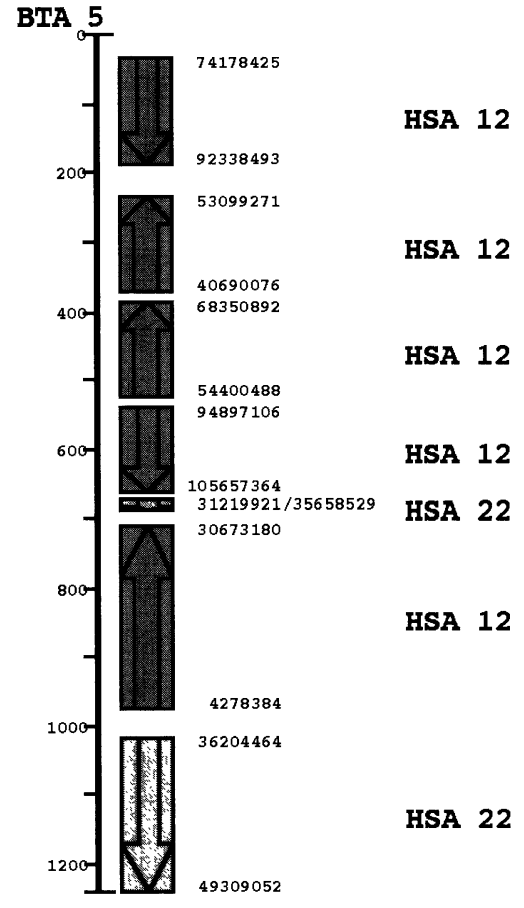

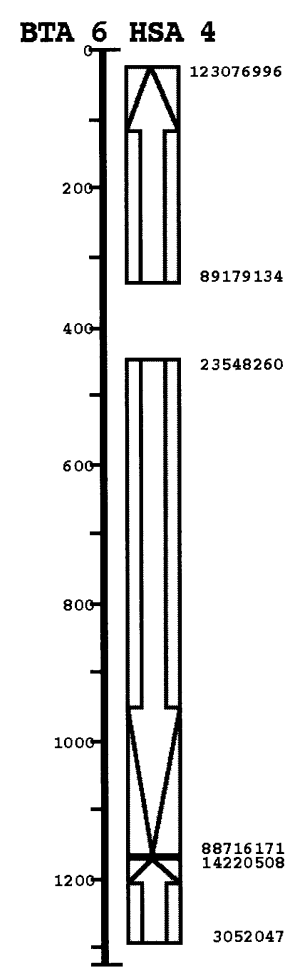

図3.ウシーヒトゲノム比較地図

第 1 番染色体から第 6 番染色体までを示した。ウシ染色体（黒太線、数字の単位は $\mathbf{c R}$ ）上に、ヒト染色体との相 同領域（シンテニー）を、 $\square$ で示した。 $\square$ の石側の数字は、ヒト染色体の塩基配列番号（単位は、bp）を示し、 口内の矢印は、シンテニーの向きを示す。その他の染色体については、Itohらの文献(2005)を参照されたい。ま た、これらの詳細は、http://www.animalgenome.org/cattle/maps/RHMap3/で閲覧できる。 


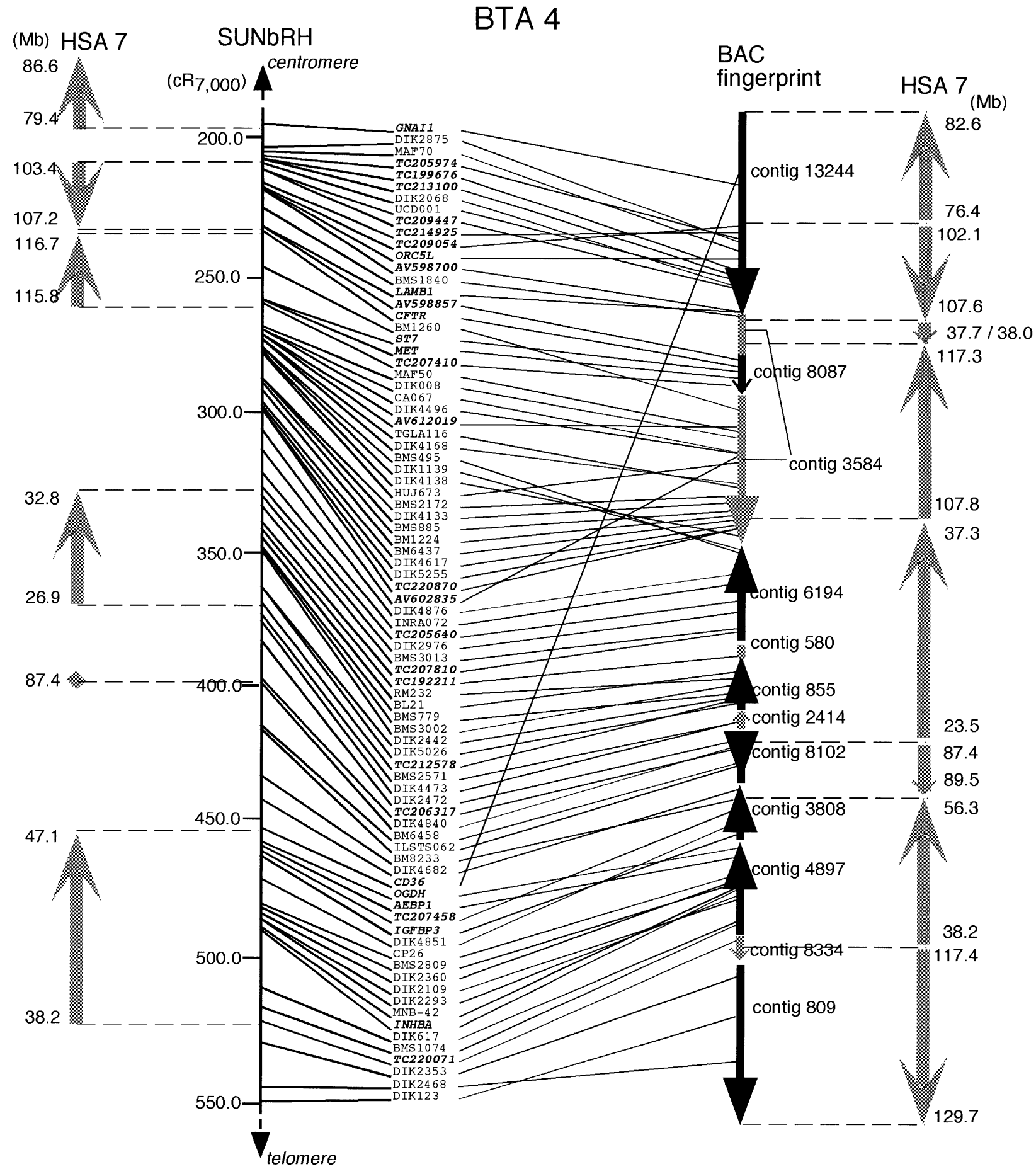

図 4. SUNbRH 地図を用いたBAC コンティグの整列化

ウシ第 4 番染色体上の霜降りの肉質に関与する領域について（Mizoshita ら 2004)、SUNbRH 地図と BACフィン ガープリント地図の情報を用いて、BAC コンティグの整列化を行った。SUNbRH 地図上のマーカーでスクリー ニングした BAC クローンのBACコンティグ内での位置を線で結んでいる。左端はSUNbRH 地図の、右端はコ ンティグに含まれる BACクローンの末端塩基配列を用いた場合のヒトゲノムとの比較地図を示す。BACコンテ イグを整列化することによって、ヒトゲノムとのシンテニーが、より詳細に明らかになった。また、この時点で 用いた BACコンティグの情報には誤りがあることも明らかになったが、(contig8087 は contig3584 の間に入る)、 その後の改訂で修正されている。 
Annotaion までを、Phase II は、SNP 検索と各品種の HapMap の作成を目的としている。

Phase Iについては、先に触れたように、すでに、ゲ ノムの 6 倍長のWGS 配列が公開されているが、現在、 ゲノムの 2 倍長の BAC $\operatorname{skim}$ (フィンガープリントで整 列化した BACクローンを、単一、もしくは、プール して、配列を読んだもの) が進行中である（http://www. hgsc.bcm.tmc.edu/projects/bovine/)。現在用いられてい るゲノム塩基配列決定の手法は、WGS と BAC skim を 組み合わせたもので、BAC skimにより、配列間のギ ヤップが埋まり、また、リピート配列によるつなぎ間 違いが改善されることが期待される。実際、現在公開 されている 6 x WGS 配列は、92\%の EST と $96 \%$ の BAC 末端配列を含んでいて、遺伝子の Annotationには ほぼ十分であると考えられているが、WGS 配列の半 分は $434 \mathrm{~kb}$ 以下の長さで、特に、遺伝子のプロモータ 一領域に相当する $\mathrm{CpG}$ island 部分はギャップになって いることが多い。

WGS 配列と BAC skim 配列は、アセンブルされて scaffold 配列となった後、scaffold 配列が含むマーカー によって、地図を通してウシ染色体上に配列される。 ウシゲノムプロジェクトにおいて、高密度地図の必要 性が認識されるのに伴い、前出の 5,000-rad と 3,000$\operatorname{rad}$ の RH 地図の充実も図られている。Lewin らのグル ープは、2005 年 12 月に、3,484 個のマーカーから成る 第 3 世代の RH 地図を報告した (Everts-van der Wind ら 2005)。これは、2,516 個の BAC 末端マーカーを含ん でおり、BACフィンガープリント地図との統合を図 ったものである。また、カナダの Moore らのグループ は、3,000-radの RH 地図に、多数の SNPをマッピング し、WGS 配列との統合を図っている (McKay ら 2006)。 また、米国ミズーリ大の Taylorらは、14 世代から成 るアンガス種の家系を用いて、多数の SNPをマッピ ングした連鎖地四を作成している。国際コンソシアム では、現在これらすべてを含んだ統合地図 (Composite map）を作成中である。この統合地図を用いて、 scaffold 配列がウシゲノム上にアセンブルされる見达 みである。

一方、Phase II は、SNP 検索と HapMap の作成を目 的としている。すでに、WGS (ヘレフォード種を使用) と、その他 6 品種 (アンガス、ブラーマン、ホルスタ イン、ジャージー、リムジン、ノルウエーレッド)の ゲノムシークエンシングにより、一万個以上の SNP が見出されている。今後、これらのSNPが各品種で タイピングされ、ハプロタイプブロック等が明らかに
されていく予定である。

\section{7. おわりに}

動物遺伝研究所が取り組んできたゲノム解析用ツー ルの開発は、時代の流れに沿って、ウシゲノムプロジ エクトへ受け継がれた。連鎖地図の高密度化を行い、 その結果を利用して構築したフレームワークに基づい た RH 地図の作成は、ウシゲノム配列決定へのきわめ て重要な貢献であったと位置付けられるだろう。 Phase I で完成度の高いウシゲノム配列が得られること が、Phase II のウシ HapMap の作成にも重要である。 SNPの正しい位置が得られなければ、ハプロタイプブ ロックの解析などできないからである。Phase II が完 了する数年後には、ウシ品種間の差が、SNP レベルで 明らかにされ、ヒトと同じように、ウシにおいても SNPアレイを用いて全ゲノムを対象にした相関解析を 行える基盤ができるだろう。その時には、ゲノム解析 に関して、皆が同じスタートラインに立つことになる。 今、その先を見通した戦略が必要とされている。

\section{謝辞}

本研究は、全国競馬・畜産振興会から助成を受けて 造成された基金によって遂行された。

\section{引用文献}

Band MR, Larson JH, Rebeiz M, Green CA, Heyen DW, Donovan J, Windish R, Steining C, Mahyuddin P, Womack JE, Lewin HA. 2000. An ordered comparative map of the cattle and human genomes. Genome Research, 10: 1359-1368.

Everts-van der Wind A, Kata SR, Band MR, Rebeiz M, Larkin DM, Everts RE, Green CA, Liu L, Natarajan S, Goldammer T, Lee JH, McKay S, Womack JE, Lewin HA. 2004. A 1463 gene cattle-human comparative map with anchor points defined by human genome sequence coordinates. Genome Research, 14: $1424-1437$.

Everts-van der Wind A, Larkin DM, Green CA, Elliott JS, Olmstead CA, Chiu R, Schein JE, Marra MA, Womack JE, Lewin HA. 2005. A high-resolution wholegenome cattle-human comparative map reveals details of mammalian chromosome evolution. Proceedings of the National Academy of Sciences of the United States of America, 102: 18526 - 18531.

Ihara N, Takasuga A, Mizoshita K, Takeda H, Sugimoto M, 
Mizoguchi Y, Hirano T, Itoh T, Watanabe T, Reed KM, Snelling WM, Kappes SM, Beattie CW, Bennett GL, Sugimoto Y. 2004. A comprehensive genetic map of the cattle genome based on 3802 microsatellites. Genome Research, 14: 1987-1998.

Itoh T, Takasuga A, Watanabe T, Sugimoto Y. 2003. Mapping of 1400 expressed sequence tags in the bovine genome using a somatic cell hybrid panel. Animal Genetics, 34: 362-370.

Itoh T, Watanabe T, Ihara N, Mariani P, Beattie CW, Sugimoto Y, Takasuga A. 2005. A comprehensive radiation hybrid map of the bovine genome comprising 5593 loci. Genomics, 85: 413-424.

Kappes SM, Keele JW, Stone RT, McGraw RA, Sonstegard TS, Smith TP, Lopez-Corrales NL, Beattie CW. 1997. A second-generation linkage map of the bovine genome. Genome Research, 7: 235-249.

McKay SD, Murdoch BM, Williams JL, Gill C, Aerts J, Law A, Wang Z, Moore SS. 2006. An Illumina based whole genome bovine-human comparative map constructed with high throughput methodology. Plant \& Animal Genome XIV, P540.

Mizoshita K, Watanabe T, Hayashi H, Kubota C, Yamakuchi H, Todoroki J, Sugimoto Y. 2004. Quantitative trait loci analysis for growth and carcass traits in a half-sib family of purebred Japanese Black (Wagyu) cattle. Journal of Animal Science, 82: $3415-3420$.

Takasuga A, Hirotsune S, Itoh R, Jitohzono A, Suzuki H, Aso H, Sugimoto Y. 2001. Establishment of a high throughput EST sequencing system using poly(A) tailremoved cDNA libraries and determination of 36,000 bovine ESTs. Nucleic Acids Research, 29: E108.

Williams JL, Eggen A, Ferretti L, Farr CJ, Gautier M, Amati G, Ball G, Caramorr T, Critcher R, Costa S, Hextall P, Hills D, Jeulin A, Kiguwa SL, Ross O, Smith AL, Saunier K, Urquhart B, Waddington D. 2002. A bovine whole-genome radiation hybrid panel and outline map. Mammalian Genome, 13: 469-474. 